교육과정평가연구 제 3 권 제 1 호(2000)

\title{
정약용(丁若鏞)의 독서교육론
}

\author{
김 왕 규
}

(한국교육과정평가원 연구원)

\section{। . 머리말}

이 글은 조선 후기 다산(茶山) 정약용(丁若鏞 : 1762 1836)의 독서교육론의 내용과 성격을 고찰하여 한국 고전 독서교육론의 이론 정립에 기초 자료로 활용하는데 연구의 목적을 두었다.

본 연구 논문은 다음과 같은 관점과 필요성 에 기초한다. 우리는 조선 후기 정약용을 중심으 로 한 실학자들에 의해 새로운 책읽기 문화가 태 동된 배경을 주목할 필요가 있다. 당대의 지식인 들은 과거 급제를 목표로 한 시부(詩賦) 위주의 문장학(文章學)에 경도되어, 현실 문제를 외면한 기득권 유지 수단으로서의 독서 문화에 함몰되어 있었다. 또한 주자학(朱子學)에 집착하여 편협한 독서 문화 구조를 형성하였다. 이러한 패러다임 속에 정약용은 독서와 삶의 현실을 유기적 통일 체로 인식하고, 부단히 현실 문제를 타개하기 위 한 학문적 노력을 아끼지 않았다.

이 시점에서 우리는 새로운 책읽기 문화가 모색되어야 하는 이유, 특히 한국 고전 독서 문 화에 대한 탐색이 필요한 이유를 조선 후기의 문 화적 분위기와 관련지어 생각해볼 필요가 있다. 입시와 고시, 그리고 입사 위주의 책읽기 문화의 폐단 속에 이 시대의 학생들은 정신적 자유와 창 조적 사고 능력을 상실한지 오래다. 그리고 서양 문화, 특히 미국 문화의 일방적 수입, 보급에 따 른 외국 문화에의 편항성 또한 민족 주체 사상에 기반한 민족 고전 문화의 부흥이란 관점에서 불 때 매우 심각한 수준에 와있다고 볼 수 있다.

이 글은 정약용의 저술에 나타난 구학(求學) 정신과 독서 자세 그리고 이에 기반한 현실 인식
을 통하여 우리가 처한 현실 상황의 문제들을 해 결하는 데 있어서 역사적 안목에 터한 해답을 얻 으려는 실천적 관심에서 출발한다. 주지하듯이 정약용은 관인(官人)이기에 앞서, 한 사람의 독서 학인(學人)으로 당대의 부조리한 현실 상황에 맞 서 그 시대의 문제를 해결하기 위해 진지한 학문 적 대결을 했던 독서인으로 이해될 수 있다. 민 족 주체 사상의 관점에서 정약용을 포함한 선인 들의 공부법(工夫法) 및 독서 교육론은 위에서 제기한 우리 시대의 문화적 위기 상황을 극복할 수 있는 가능성을 제시하고 있다는 점에서 매우 의미있는 연구 영역이라고 할 수 있다.

연구자는 이 글을 통하여 정약용의 독서교육 론의 내용과 그 특성을 집중적으로 분석, 고찰하 여 한국 고전 독서교육론 정립에 초석을 마련하 고자 한다. 이 글은 위에서 논의한 연구 목적과 필요성에 의해 수행되는 연구의 첫걸음이 될 것 이다.

\section{II. 정약용의 독서교육론의 내용과 성격}

\section{1. 독서 목적 및 본질에 대한 인식}

우리가 살고 있는 시대를 지식, 정보화 사회라 고 한다. 적어도 표면적으로 볼 때, 지식과 정보 가 사회를 움직이는 중요한 요소로 작용한다. 그 리고 이전 시대와는 달리 지식과 정보가 특정 계 층의 전유물이 아니고, 대중에게 열려 있으며 또 한 지식과 정보를 빨리 수용, 생산함으로써 경제 
적인 이득을 마련할 수도 있다.

정보화 사회에서는 정보가 한층 중요하게 취 급되며, 정보의 양이 엄청나게 증대되고 그만큼 빨리 소멸되는 특성이 있다. 그리고 정보의 단순 수용보다는 능동적인 이해를 요구하고 있다. 또 한 정보의 질이 한흥 더 깊어졌으며, 정보가 표 출되는 형태가 다양해 졌다. ${ }^{1)}$

그런데 나는 이른바 지식 정보화 사회 시대 에 다음과 같은 질문을 스스로에게 던져 본다. 무수히 쏟아지는 정보를 귾임없이 획득하고 지식 을 반복적으로 재생산하여 우리가 우리 자신과 인류의 미래를 위해 할 수 있는 일이 무엇인가? 지식 정보화 사회에서 책을 읽는 다는 것의 의미 는 무엇일까? 그리고 독서의 본질을 어디에 두어 야 할 것인가?

현행 고등학교 「독서」 교육의 목표는 “의사 소통 행위로서의 독서의 본질과 원리를 이해하 고, 글의 성격과 독서의 목적에 따라 효율적인 방법으로 글을 읽을 수 있으며, 바람직한 독서 태도를 지닐 수 있는 것"2)으로 설정되었다.

이와같이 독서의 본질을 의사소통의 과정으로 해석할 때에 우리는 글의 의미를 글의 문면에서 찾지 않고 문맥, 상황, 필자의 숨은 의도, 그리고 독자의 필요에서 종합적으로 구셩해 닐 수 있다.3)

전통적으로 우리의 선현들은 독서 교육의 목 적과 본질을 지식과 정보를 획득하거나 언어 사 용 기능의 신장이라는 인지적 측면보다는 정의적 영역 곧 독서를 통해 마음의 정서를 함양하고 여 유와 멋을 찾으며 감동을 느끼는 측면을 강조해 왔다. 더 나아가 독서 교육의 본질 및 의의를 단 순히 개인의 인격 수양에 둔 것이 아니라 나라를 걱정하고 백성을 사랑하는 데까지 설정하였다. 이 점은 정약용을 중심으로 한 조선 후기 일군의 실학자들의 독서교육론에 보다 더 강조되어 나타 난다.

독서의 목적 및 본질에 대한 정약용의 인식을

1) 이재승, 정보화 사회와 독서 교육, 「독서연구 5 호, 한국독서 학회, 2000. 87면

2) 교육부, 국어과 교육과정, 1997,131 면

3) 교육부, 고등학교 국어과 교육과정 해설, 1992, 183면
살펴보기로 하자. "천지간에 외롭게 서있는 내가 의지하여 천명으로 삼을 것은 오로지 책이 있을 뿐이다."4)라고 말한 정약용은 "오직 독서 이 한 가지 일이, 위로는 옛 성현을 좇아 함께 할 수 있게 하고 아래로는 백성을 길이 깨우칠 수 있게 하며, 신명에 통달하게 하고 임금의 정사를 도울 수 있게 할 뿐 아니라, 인간으로 하여금 짐승과 빌레의 부류를 벗어나 저 광대한 우주를 지탱하 게 만는다"고 하면서, 독서는 바로 우리들의 본 분이라고 인식하였다.5)

인간으로 하여금 금수와 구별되게 하고 광대 한 우주를 지탱할 수 있게 하는 근원으로 독서의 본질을 설정한 정약용은 독서. 저술의 궁극적 의 미와 본질을 다음과 같이 거듭 강조했다.

대략 저서하는 방법을 말해보면 경전(經 典)에 대한 저서를 제일 우선으로 해야하고 그 다음은 세상을 경륜하고 백성에게 혜택을 베풀어주는 학문이 그 다음이며 국경(國境) 을 지키고 성을 쌓는 제도로 회침을 막아내는 그러한 분야도 소홀히 할 문제가 아니다. 자 질구레한 이야기들로 한 때의 괴상한 웃음이 나 자아내는 책이라든지, 진부하고 새롭지 못 한 이야기나 지리멸렬하고 쓸모없는 어떤 의 론(議論)을 책으로 만드는 일은 다만 종이와 먹을 허비하는 것에 지나지 않으니 차라리 손 수 맛있는 과일이나 영양가 높은 채소를 심어 살아있는 동안의 생활이나 넉넉하게 하는 것 만 못하다.6)

새롭지 못한 진부한 담론(談論), 무용한 의론 (議論) 등을 책으로 만드는 일은 채소를 심어 생 활에 이용할 수 있는 것만 못하다고 하면서, 독

4) 丁若鏞, 「寄二兒」, 『與猶堂全書』第一集 第二十一卷 且吾子立天地 所依爲命 唯文墨是已

5) 丁若鏞, 『與猶堂全書』

唯有讀書一事 上足以追配聖賢 下足以永詔蒸黎 幽達 鬼神之情狀 明贊王覇之謨猷 超越禽蟲之類 撑柱宇宙 之大 此方是吾人本分

6) 丁若鏞, 「示二者家誡」『與猶堂全書』第一集 第十八卷 大較著書之法 經籍爲宗 其次經世澤民之學 若關防器 用之制 有可以禦外侮者 亦不可少也 若夫頊細零星之 說 苟取一時之詼笑 與夫陳腐不新之談 支離無用之論 徒費紙墨 不如手植珍果佳蔬 以博生前之生理也 
서. 저술의 궁극적 의미를 “경세택민(經世澤民)" 에 두었다. 독서 저술의 목적과 본질을 세상을 경영하고 백성을 이롭게 하는 데 설정한 정약용 은 옛사람의 글귀를 따서 글이나 짓고, 벌레나 물고기 등류에 대한 주석이나 내고, 소매 넓은 선비 옷을 입고서 예모(禮貌)만 익히는 것은 학 문이 아니라고 하면서, 참된 선비의 학문은 본디 나라를 다스리고 백성을 편안히 하고 오랑캐를 물리치고 재용(財用)을 넉넉하게 하고 문식(文 識)과 무략(武略) 등을 갖추어야 한다고 거듭 주 장하였다.7)

독서의 목적 및 본질을 자기 완성이라는 수기 (修己)의 측면에 국한시키지 않고, 백성을 널리 이롭게 한다는 치인(治人)의 범주까지 지평을 확 보한 인식은 사실 정약용에게서만 찾아 볼 수 있 는 논리는 아니었다. “독서왈사(讀書曰士)"라고 하여 선비의 본질을 독서라고 규정한 박지원(朴 趾源)은 고전을 읽어 지혜를 온축하고 덕성을 함 양하여 목민관(牧民官)이 되면 비로서 사대부가 될 수 있다고 하였다.8) "지위가 없음을 걱정하지 말고, 그 지위에 설 수 있는 자격이나 요건이 되 는 지를 근심하라."라는 글9)에 나타난 것처럼, 책읽기를 통한 “수기치인지술(修已治人之術)"에 대한 공부는 종정(從政)에 앞서 선비가 갖추어야 할 의무이기도 하였다.

선비가 자기의 본분인 독서에 충실할 때, 그 효과에 대해 박지원은 "한 선비가 책을 읽으면 그 은택이 온 천하에 두루 미치고, 영원토록 그 공로가 드리워진다. 「주역(周易)」에 '나타난 용이 밭에 있으니, 온 천하가 밝게 빛난다.'라고 하였 으니, 그 말은 바로 “독서지사(讀書之士)'를 일컨 는 말이다."10)라고 하였다.

7) 丁若鏞, 「俗儒論」、與猶堂全書』第一集 第十二卷 眞儒之學 本欲治國安民 攘夷狄裕財用 能文能武 無 所不當 豈尋章摘句 注蟲釋魚 衣逢掖習拜揖而已哉

8) 朴趾源, 「放滪閣外傳」, 『燕嚴集』卷 8 讀書曰士 從政爲大夫 有德爲君子

9) 孔子, 「里仁」, 『論語』 子曰 不患無位 患所以立 不患莫己知 求爲可知也 10) 朴趾源, 「原士」, 『燕巌集』卷十

一士讀書 澤及四海 垂功萬世 易曰 見龍在田 天下文 明 其謂讀書之士乎
학문적 가치와 독서의 목적을 세상을 경영하 고 백성을 이롭게 하는 데 두었던 정약용은 독서 군자의 요건을 독서의 본질과 관련지어 다음과 같이 밝혔다.

\section{반드시 처음에는 경학공부를 하여 밑바탕} 을 확고히 한 후에 옛날의 역사책을 섭렵하여 옛 정치의 득실과 정치가 잘 되던 이유, 난리 가 났던 이유 등의 근원을 캐볼 뿐 아니라 실 용의 학문에 마음을 두고 옛사람들이 나라를 다스리고 세상을 구했던 글들을 즐겨 읽도록 해야 한다. 이런 뜻을 마음에 새기고 만 백성 에게 혜택을 주고 만물을 풍윤하게 자라게 해 야겠다는 뜻을 가지고 있을 때 비로서 독서군 자가 될 수 있다.11)

정약용이 말한 '실용의 학문'이란 바로 나라를 다스리고 세상을 구했던 책이었으며, 백성을 윤 택하게 할 수 있는 의지를 가지고 독서 저술을 통해 그 방법을 구현할 수 있는 사람이 바로 진 정한 독서 군자라고 하였다. 독서를 통하여 은택 과 공로를 백성들에게 널리 펼치고 천하를 문명 화시킬 수 있다는 박지원과 정약용의 담론에서 우리는 독서 교육의 본질 및 목적을 어떻게 설정 할 것인가라는 물음에 일정한 시사점을 얻을 수 있을 것이다. 잠정적으로 고난한 민족의 역사를 통찰하고, 민족과 국가의 당면한 문제를 주체적 으로 해결할 수 있는 다소 거시적인 안목으로 독 서의 본질 및 목적을 달성해야 할 것이다.

또한 우리는 전통 시대에 '선비'로 명명되던 인간상이 이 시대에도 요청되며, 그 본질이 무엇 인지에 대한 논의의 단서도 마련할 수 있을 것이 다. 명실(名實)에 맞는 선비 내지 지성인은 생활 의 편의를 제공하는 과학 문명의 이기와는 질적 으로 다른 차원에서 민족의 운명에 도움을 줄 수 있다. 독서를 통해 천지 자연의 이치를 궁구(窮 究)하여 지혜를 배우고, 터득한 지혜를 세상을 경영하고 백성을 이롭게 하는 실용적 차원에서

11）丁若鏞, 「寄二兒」, 『與猶堂全書』第一集 第二十一卷 必先以經學立著基址 然後涉獵前史 知其得失理難之 源 又須留心實用之學 樂觀古人經濟文字 此心常存澤 萬民育萬物底意思然後 方做得讀書君子 
교육과정평가연구 제 3 권 제 1 호(2000)

활용한 선현들의 독서에 대한 인식은 이 시대의 독서교육론의 방향 설정에 일정하게 영향을 줄 수 있을 것이다.

한편 독서의 본질 및 목적과 관련지어 우리 시대의 문제를 해결하고 그 대안을 제시하기 위 한 사상적 근거, 사유 체계를 독서를 통하여 어 떻게, 무엇으로 마련할 것인가라는 다소 거시적 인 문제 인식이 우리에게 거듭 요구된다. 독서의 본질에 대한 인식의 지평을 넓히는 문제일 뿐만 아니라, 미래의 도전에 응전할 수 있는 논리 확 보라는 차원에서 거듭 제기되고 폭넓게 논의되어 야 할 문제일터이지만, 우선 다음 글을 통하여 논의의 단서를 마련하고자 한다.

약용이 유배지에 있던 18년 동안 경전 연 구에 온 마음을 기울여 지은 책으로 r시」, r 서」, r예」, r악」, ${ }^{\circ}$ 역」, r춘추」및 r사서」에 관 한 이치를 연구해 모두 230권을 저술했는데, 정밀하게 연구하고 오묘하게 깨달아서 옛날 성인의 근본 뜻을 많이 얻었다. 시문집으로 편찬해 놓은 게 모두 70 권으로 많은 부분이 관직에 있을 때 저술했던 것이다. 기타 저술 로는 나라의 전장(典章) 및 백성 다스리는 일, 옥사에 관한 것, 국방에 관한 것, 국토 지 리에 관한 것, 의약에 관한 것, 글자의 분석에 관한 것 등 무려 200여 권이나 된다. 이것들 은 모두가 성인들의 경전에 근본을 두고 있고 이 시대의 중요한 일을 알맞게 처리할 수 있 도록 힘썼기 때문에 없어지지 않는 다면 더러 는 인용하여 사용 할 사람도 있을 것이다.12)

그의 학문은 18 년 간의 유배 시절에 이룩되었 다. 이 시기에 그는 정치, 경제, 사회 제도 등 국 가 경영과 관련된 일체의 문제에 관해 학문적 검 토를 가하였다. 또한 이런 현실적 문제를 해결하

12）丁若鏞，，「自撰墓地銘」(壙中本)，『與猶堂全書』第 一集, 墓誌銘

鏞在謫十有八年 專心經典 所著詩書禮樂易春秋及四書 諸說 共二百三十卷 精研妙悟 多得古

聖人本旨 詩文所編共七十卷 多在朝時作 雜篡國家典

章及牧民按獄 武備橿域之事 醫藥文字之辨 殁二百卷 皆本諸聖經而務適時宜 不泿則 或有取之者矣
는 데 필요한 사상적 근거를 마련하기 위해 유교 경전을 전면적으로 재검토하였다. 정약용이 그토 록 비장하게 학문, 독서에 몰두했던 것은 '우국애 민(憂國愛民), 즉 나라를 걱정하고 백성을 사랑 하는 마음에서였다. ${ }^{13)}$

고전(古典)에 근본하여 나라를 경영하고 백성 들을 널리 이롭게 하는 독서 전략을 마련했던 정 약용은 독서와 저술의 지향점을 '우국애민(憂國 愛民)'과 '시무(時務)'에 두었다. 독서교육론의 논 의 범위를 벗어나는 다소 비약적인 논의이지만, 정약용의 담론에서 적어도 우리는 다음 두 가지 논의의 단서를 얻어낼 수 있다. 그 하나는 우리 시대의 문제를 헤결하고 그 대안을 제시하기 위한 사상적 근거, 사유 체계를 고전에 근본해 야 한다는 점이다. 그리고 다른 하나는 우리 시 대의 문제를 해결하기 위한 대안 제시 및 방향 설정이 소아적인 차원이 아닌 대승적 차원 곧 ‘우국애민(憂國愛民)’ 내지 ‘경세텍민(經世澤 民)'의 방향으로 설정되어야 한다는 점이다. ${ }^{14)}$

\section{2. 독서의 원리 및 방법}

독서의 원리는 독서를 호율적으로 하는 데 필 요한 여리 측면들이라고 할 수 있다. 여기서 원 리란 효율적인 독서에 꼭 필요한 요소와 방법이 라고 할 수 있으며, 독서 기능이라고도 할 수 있 다.15) 독서의 원리는 독서의 준비, 독해, 독해 과 정의 인식, 독서와 학습 방법 등의 기능을 효과 적으로 수행하는 데 필요한 원리 및 전략에 관한 절차적 지식이 중심 내용 된다.16)

독서의 원리 및 독서 방법에 대한 정약용의 담론을 살펴보기로 하자. 정약용은 독해의 과정 에서 자기 주관에 근거한 해석을 다음과 같이 강 조하였다.

13) 박희병편역, 선인들의 공부법, 창작과 비평사, 181면

14) 고전의 성격과 목록 그리고 대안 제시의 방향에 대한 구체적 논의는 본 고의 성격과 범위를 벗어나 는 문제라고 생각되어, 별고의 작업을 마련할 필요 가 있을 것이다.

15 ) 교육부, 고등학교 국어과 교육과정해설, 1995,190 면 16) 교육부, 국어과 교육과정, 1997,130 면 
신이 가만히 엎드려 생각하건대, 경서를 해 석하는 데는 세 가지 방법이 있습니다. 첫째 는 전하여 들은 것, 둘째는 스승의 가르침을 받은 것, 셋째는 자기의 뜻으로 해석하는 것 입니다. 자기의 의사로 해석한 것은 아무리 천 백년 뒤에 출생하였어도 천 백년 이상의 것을 뛰어넘어 입증할 수 있습니다.17)

책을 읽는 독해 방법에 세 가지가 있다고 하 면서, '전문(傳聞)', 사승('師承)', ‘의해(意解)' 가운 데 자기의 뜻으로 해석하는 '의해'가 중요하다고 했다. 글의 의미 이해에 영향을 끼치는 글 요인 은 글의 종류, 글의 형식 구조, 그리고 글의 내용 구조로 나눌 수 있다. 그리고 글의 의미 이해에 영향을 끼치는 독자 요인은 독자의 배경 지식과 독자의 독서 목적이다. '스키마'라고 불리는 독자 의 배경 지식은 독해의 과정에서 매우 중요한 요 소로 작용하는 데, '자기의 뜻으로 글을 해석하는 방법’은 고도화된 독자의 배경 지식을 요구한다.

책 읽기 방법은 글의 종류나 형식에 따라 달 라지겠지만, 한편으로 독자의 글을 읽는 목적에 따라 독서의 방법은 달라진다. 정보를 전달하기 위한 설명문에서는 글의 내용 파악, 설득적인 논 설문에서는 지은이의 주장과 근거 파악, 소설이 나 극본에서는 사건의 전개 과정 알기 그리고 시 에서는 정서 파악이 중요하다. 글을 읽는 목적에 따른 독서의 방법으로는 필요한 정보만을 찾아서 읽기, 내용을 자세히 읽기, 중심 내용만 찾아서 읽기 등을 들 수 있다.

이와 같은 기능적인 측면에 중점을 둔 독서 방법과는 달리 정약용은 독서의 본질 및 목적과 관련지어 독서의 방법을 다음과 같이 주장했다.

책을 읽는 데는 대개 방법이 있다. 세상에 도움이 되지 않는 책은 구름 가듯 물 흐르듯 읽어도 되지만, 만일 백성이나 나라에 도움이 되는 책을 읽는 경우라면 반드시 문단마다 이 해하고 구절마다 탐구해가면서 읽어야 하며,

17）丁若鏞, 「十三經策」、與猶堂全書』第一集 第八卷 臣䩹伏念 釋經之法有三一曰傳聞 二曰師承 三曰意解 意解者 雖生於千百歲之下 而有能超據乎千百歲之上
한낮의 졸음이나 쫓는 수단으로 삼아서는 안 된다.18)

학문과 독서의 본질 및 목적을 ‘우국애민'(憂國 愛民)에 설정한 정약용은 백성이나 나라에 도움 이 되는 책은 정독할 것을 주장했다. 단어나 문 장 수준이 아닌, 담화나 텍스트 수준의 글을 읽 는 것은 매우 수준 높은 정신 기능을 필요로 한 다. 곧 글을 읽고 의미를 재구성하며 숨겨진 의 도를 찾아내는 작업은 정밀한 독서 전략을 요구 한다. 특히 정약용의 독서관에 터하면, 세상을 경 영하고 백성을 사랑하는 주제가 담긴 글은 '문단 마다 이해하고, 구절마다 궁구하는 독서 방법이 필요한 것이다.

독서의 원리에서 독해에 대한 이해는 매우 중 요하다고 할 수 있다. 독해는 글 전체의 내용 파 악을 뜻한다. 이에는 글의 형식이나 구조에 대한 이해, 글의 내용에 대한 이해, 필자의 의도나 표 현 방법에 대한 이해, 독자 자신의 독서 목적과 방법에 대한 이해, 독자의 독해 정도에 대한 이 해 등이 모두 포함된다. 글을 읽고 내용의 타당 성과 공정성, 자료의 정확성과 적절성 등을 판단 하는 비판적 독해, 글에서 가장 감동적인 부분을 찾고, 이유를 말하는 감상적 독해, 긴 글을 읽고 글 전체 내용을 요약하는 글 전체의 독해, 그리 고 단어, 문장, 문단의 독해 등이 독서 원리의 중요 영역이라고 볼 수 있다.19)

정약용은 어떻게 책을 읽을 것인가라는 물음 에 다음과 같은 논의를 전개했다.

내가 몇 년 전부터 독서에 대하여 약간 알 게 되었다. 한갓 책을 읽기만 한다면 비록 날 마다 천백 편을 읽었다하더라도 책을 읽지 않 은 것과 같다. 책을 읽을 때에 한 글자라도 의 미가 밝혀지지 않은 곳을 만난다면 넓게 고찰 하고 세밀하게 연구하여 그 근본 뿌리를 알아 야 하며, 그런 다음 (그 글자가 사용된 문장을

\footnotetext{
18）丁若鏞, 『與猶堂全書』 讀書總皆有法 凡無益於世之書 讀之如可如行雲流水 若其書有裨於民國者讀之 須段段理會 節節尋究不可 作午牕禦眠楯而已

19) 교육부, 국어과 교육과정, 1997, 132 133면
} 
이 책 저 책에서)선택하고 안배하여 문장으로 엮어 나태내야 한다. 날마다 이런 식으로 책 을 읽는다면 한 권의 책을 읽을 때에 아울러 수백 권의 책을 엿볼 수 있게 된다. 이렇게 읽 어야 읽은 책의 의리를 환하게 꿰뚫어 알 수 있게 되는 것이니 이 점 알지 않을 수 없다.20)

글 내용은 그 글을 구성하는 단어들의 의미로 이루어진다. 따라서 단어의 의미를 이해하지 못 하고는 글의 의미를 파악할 수 없다. 독해의 정 도를 가장 잘 예언하는 요인이 바로 단어의 이해 정도라고 한다. 그만큼 단어의 이해는 독서에서 중요하다. 정약용은 책을 읽다가 한 글자라도 뜻 이 분명하게 드러나지 않는 경우에는 '널리 살피 고 세밀하게 조사하여 그 (뜻의)근원을 밝혀야 한다'고 말했는데, 글자의 뜻을 고구(考究)하는 구체적 예를 다음과 같이 제시하였다.

「자객전(刺客傳),같은 책을 읽을 때, '조 취도'(祖就道)라는 구절을 보면 “조(祖)라는 것은 무슨 뜻입니까?"라고 묻게 되고 선생은 “이별할 때 지내는 제사다."라고 대답할 것이 다. 그렇다면 “그러한 제사에다 꼭 조(祖)라 는 글자를 써야 할 특별한 까닭이 있습니까" 라고 다시 묻게 되고 선생이 "잘 모르겠다." 라고 대답하면 집에 돌아와 자서(字書)에서 조(祖)라는 글자의 본뜻을 찾아보고, 자서(字 書)에 있는 것을 근거로 하여 다른 책을 들추 어 그 글자를 어떻게 해석했는가를 고찰해 보 고 그 근본 된 뜻만 아니라 지엽적인 뜻도 철 해 놓고 통전(通典)이나 통지, 통고(通考) 등 의 책에서 조제(祖祭)의 예를 모아 책을 만들 면 오래도록 남을 책이 될 것이다. ... 어찌 주 자(朱子)의 격물(格物) 공부를 크게 즐기지 않겠느나. 오늘 한 가지 물건에 대하여 격(格) 하고 내일 또 한 가지 물건에 대하여 격(格) 하는 사람들도 이렇게 글자를 알아낸다. 격

20) 丁若鏞, 『與猶堂全書』第一集 二十一卷

吾自數年來 頗知讀書 徒讀 雖日千百遍 猶無讀也 凡讀書 每遇一字有名義不曉處 須博考細究 得其原根 仍須詮次成文 日以爲常 如是則讀一種書 兼得旁窥百 種書 仍可於本書義理曉然貫穿 此不可不知也
(格)이라는 뜻은 가장 밑까지 완전히 다 알 아낸다는 것을 의미하는 것이니 가장 밑에 까지 알아내지 못한다면 아무런 의미가 없다.21)

'조(祖)'자를 예로 들면서, 단어의 의미를 이해 하기 위해서 자전을 이용하여 단어의 의미를 알 고, 용례를 조사하여 단어의 다양한 의미까지도 공부할 것을 주장하고 있다. 이 글에서 우리의 주목을 요하는 것은 독해의 원리로 '격(格)'을 강 조하고 있다는 점이다. 단어나 사물의 가장 근원 까지 완전히 다 알아내는 것을 '격'이라고 했다. 정약용은 '격'을 통한 독서의 과정과 호과에 대 해, “오로지 『주역』1책만을 책상 위에 두고 밤 낮으로 마음을 가라앉혀 탐구했더니, 계해년 (1803) 늦봄부터는 눈으로 보는 것, 손으로 만지 는 것, 입으로 읋는 것, 마음으로 생각하는 것, 붓으로 베껴 쓰는 것에서부터, 밥상을 대하고 뒷 간에 가고 손가락을 틍기고 배를 문지르는 것에 이르기까지 어느 하나 『주억』이 아닌 적이 없었 다. 그리하여 그 이치를 환히 깨달았다."22)라고 말하여 독서 방법의 하나로 '격'의 과정과 체득 결과를 구체적으로 밝혔다.

여기에서 우리는 '격(格)'의 의미를 독서 교육 론의 차원에서 어떻게 해석하고 이를 이론화할 수 있을까라는 문제를 제기해 볼 수 있다. 단어 의 의미 이해는 그 낱말의 사전적 의미 이외에 그 낱말과 관련된 다른 낱말을 이해하게 하며 특 히 그 낱말이 함축하고 있는 사실이나 개념을 이 해하게 하는 데 그 궁극적인 목적이 있다. 이러 한 점 때문에, 도구적 관점에서의 어휘 지도보다 는 이른바 인지적인 관점에서의 어휘 이해 및 지

21）丁若鏞, 『與猶堂全書』第一集 第二十一卷 如讀刺客傳 遇既祖就道一句 問曰祖者何也 師曰餞別 之祭也 曰其必謂之祖者何義 師曰未詳 然後歸而至其 家 抽字書見祖字之本義 又因字書轉及他書 考其箋釋 採其根本 掇其枝葉 又如通典通志通考等書 考祖祭之 禮 彙次成書 便足不朽 … 豈不大樂朱子格物之工也 只如此 今日格一物 明日格一物者 亦須如是著手 格 者窮極到底之意 不窮極到底 亦無所爲益也

22) 丁若鏞, 『與猶堂全書』

專取周易一部 措諸案上 潛心玩索 夜以繼書 蓋自癸 亥暮春 目之所視 手之所操 脣之所吟 心志之所思索 筆墨之所鈔錄 以至對飯登圆 彈指捫腹 無一而非周易 兓融會貫洽 
도가 주목을 받고 있다. 특히 인지심리학의 대표 적인 이론의 하나인 스키마 이론의 관점에서는, 어휘를 단순히 언어 사용을 위한 도구로 보지 않 고 개인의 경험이나 지식과 관련된 하나의 개념 으로 파악한다. 스키마는 개인 각자가 가지고 있 는 경혐과 지식의 총체를 일킨는 말이다.23) 독자 가 지닌 스키마를 이용하여 개인의 경험이나 지 식과 관련된 하나의 개념으로 단어의 의미를 파 악하는 것은 어휘력 확충에 기여할 뿐 만 아니라 개인의 인지적인 능력, 곧 사고력의 증진을 확장 하는 것으로 이해된다. 그리고 단어나 사물의 가 장 밑까지 완전히 다 알아내고 새로운 개념을 형 성하는 한편 이를 확대 유추하여 '격믈(格物)'의 경지에 이를 수 있다면, 독해의 과정과 절차가 독자에게 올바로 구현되었다고 볼 수 있다.

독서 방법에서 발췌, 기록의 중요성은 아무리 강조해도 지나치지 않을 것이다. 글을 읽고 글의 내용을 간추리기, 요약하기, 중심 내용 파악하기 등의 독서 활동에서 기록과 메모는 중요한 학습 방법이라고 할 수 있다. 초록(鈔錄)과 발췌의 중 요성과 방법에 대해 정약용은 다음과 같이 말했다.

책을 읽을 때 학문에 보탬이 될 만한 내용 이 있으면 발췌하고 그렇지 않은 내용은 물리 치고 눈을 주지 말아야 한다. 이렇게 한다면 비록 백 권의 책이라 할지라도 열흘의 공부에 지나지 않을 것이다.24)

정약용은 남의 저서에서 도움이 될만한 요점 을 추려내어 책을 만들 때에는 우선 자기 자신의 학문에 주견이 뚜렷해야 판단기준이 마음에 세워 져 취사선택하는 일이 용이할 것이라고 하면서 요점을 간추리거나 책을 초록할 때에 ‘멀리 보는 눈'[長慮]과 '달관하는 안목'[達觀]이 필요하다고 강조했다. ${ }^{25)}$ 그리고 “초서(鈔書)하는 방법은 반드 시 먼저 자기의 뜻을 정해 만들 책의 규모와 목

23) 이재승, 국어 교육의 원리와 방법, 박이정,1998. 247면 24)丁若鏞, 「答二兒」, 『與猶堂全書』第一集 第二十一卷 凡得一書 惟吾學問中有補者 採掇之 不然者 手牛勿留眼 雖百卷書 不過旬日之工耳

25) 丁若鏞, 「答二兒」『與猶堂全書』第一集 第二十一卷 鈔書之法 吾之學問先有所主然後 權衡在心 而取捨不 難也. … 臑子無長慮達觀可歎
차를 세운 후에 비로서 남의 책에서 간추려 내야 조리에 들어맞는 모미가 있다."26)라고 말하여, 글 을 읽고 필요한 정보를 간추리거나 요약하여 독 자에게 유용한 자료를 재구성하는 작업에서 유의 해야 할 점을 밝혔다.

\section{3. 독서군자(讀書君子)의 기상(氣象) 과 자세}

독서 교육에서 독서의 태도 영역은 독서에 관 한 정의적 특성인 동기, 습관, 태도에 관한 이론 을 바탕으로 다양한 독서 상황에서 실제로 글을 읽는 교수. 학습이 중심 내용이 된다. 현행 $r$ 독 서」 교육 과정의 목표에서도 "바람직한 독서 태 도를 지닌다."라고 하여 독서에서의 정의적 영역 을 강조하였다.27) 독서의 태도를 구체적으로 살 펴보면, 독서 동기 및 태도에서는, “독서를 통하 여 삶을 성찰하고, 인간과 사회를 이해하려는 태 도를 지니며, 독서가 개인의 성장 및 사회 발전 에 미치는 영향을 인식하고 그 가치를 인정하는 한편 독서의 즐거움을 경험하고, 즐겨 읽는 태도 를 지닌다."로 하위 요소를 구성하였다. 그리고 독서 습관의 하위 요소는 "평생 독서의 가치를 인식하고 서점과 도서관을 즐겨 찾는다. 독서에 홍미와 관심을 가지고 다양한 읽을거리를 고루 읽는다. 상황과 처지에 맞게 단기 또는 장기 독 서 계획을 세운다. 읽은 글의 내용이나 책의 목 록을 정리하는 습관을 지닌다."로 설정되었다. ${ }^{28)}$

이 절에서는 독서군자(讀書君子)의 기상(氣象) 과 독서 태도 및 자세에 관한 정약용의 담론을 살펴보기로 하자. 그는 일찍부터 커다란 학문적 포부를 지녔던 바, "나는 스무살 때 우주 사이의 모든 일을 가져다가 ( 그 원리와 이치를) 모두 발명(發明)하고 일제히 정돈하고 싶었다.”라고29)

26）丁若鏞, 「寄游兒」、與猶堂全書』第一集 第二十一卷 凡鈔書之法 必先定己志立吾書之規模節目 然後就彼抽 出來 方有貫串之妙

27) 교육부, 국어과 교육과정, 1997. 131면

28) 교육부, 국어과 교육과정, 1997. 134면

29) 丁若鏞, 與猶堂全書』第一集 第十八卷 余年二十時 欲盡取宇宙間事 一齊打發 一齊整頓 至 三十四十 此意不衰 
고백했다. 그는 모르는 게 있으면 밥 먹는 것을 잊기도 하고 잠자는 것을 잊기도 할 만큼 지독하 게 공부했고 골똘히 사색했다. 큰 학문은 거져 이루어지는 게 아니요, 목숨을 걸고 하는 것임을 일째워주는 대목이다. ${ }^{30)}$

정약용은 중국의 진(秦)나라, 한(漢)나라 이후 수 천년이 지난 지금 수 천리 떨어진 요동만 동 쪽에 위치한 조선에서 공자시절의 옛 예를 다시 파악해 본다는 것은 매우 중요한 일이라는 생각 을 지니고 있었다.31) 이 글에서 우리는 정약용이 지녔던 고전에 대한 사명감을 엿볼 수 있다. 그 사명감이란 끊어진 도(道)를 다시 회복하겠다는 의지 외에 다름 아니다. "사나이의 가슴속에는 늘 가을 매가 하늘로 치솟아 오르는 기상이 있어 야 하며, 건곤을 작게 여기고 우주를 자신의 손 바닥 안에 있는 것처럼 여겨야 한다"32)라는 말에 서 우리는 정약용의 군은 의지와 기상을 거듭 확 인할 수 있는 데, 정약용이 일 생을 바쳐 자임(自 任)했던 유학의 도(道)란 관념 지향적인 것이 아 니라 '우국애민(憂國愛民)'의 정신을 구현할 수 방향으로 설정된 도(道)라고 할 수 있다.

독서가 사회 발전에 미치는 영향을 인식하고 그 가치를 인정한 정약용은 유배지에서 두 아들 에게 보낸 편지를 통하여 “집안이 망했기 때문에 더욱 정진해야 할 것은 역시 독서하는 일뿐이다. 독서는 바로 인간의 제일가는 깨꼿한 일로써 부 귀한 집안의 자제라고 해서 그 진미를 맛보게 해 주는 것도 아니고 아주 외딴 시골 자녀들에게도 그 오묘한 이치를 터득시켜 주지 않는다. 반드시 벼슬아치 집안의 자제로서 어려서부터 듣고 본 바도 있는데 중년에 재난을 만나 너희들 같은 애 들이 진정한 독서를 하기에 가장 좋은 것이다. 그네들이 책을 읽을 수 없다는 것이 아니라 뜻도

30) 박희병편역, 『선인들의 공부법』, 창작과 비평사, 181 면

31) 丁若鏞, 『與猶堂全書』第一集 第二十一卷

籥自意 秦漢以來 數千年後 遼灣以東數千里外 還得洙 泗舊禮 亦非小事

32) 丁若鏞, 『與猶堂全書』第一集 第二十一卷

男子漢胸中 常有一副秋隼騰霄之氣 眼小乾坤 掌輕宇 宙 斯可已也
의미도 모르고 그냥 책을 읽는다고 해서 책을 읽 는 것이 아니기 때문이다." 33 )라고 하여, 쳬족(廢 族)의 자제로서 가져야 할 독서에 대한 자세를 강조했다.

정약용은 "학문에 있어서 가장 중요한 내용은 효(孝)와 제(悌)로서 그 근본을 삼고 예와 악으 로써 수식을 하며 정치와 형벌로써 도움을 주고 병법이나 농학으로써 그 이익을 주겠다는 생 각"34)을 가져야 한다라고 하면서 글을 읽는 사람 이 갖추어야 할 가장 중요한 자세를 다음과 같이 밝혔다.

독서할 때는 반드시 근기를 세워야 하는 법인데 근기란 무엇을 말한다고 생각하느냐? 학문에 뜻을 두지 않으면 독서할 수 없는 것 인데 학문에 뜻을 두는 것도 반드시 먼저 근 기가 세워져 있어야 한다. 그렁다면 근기란 무엇이겠느냐? 근기란 오직 효와 제 그것 뿐 이다. 먼저 효와 제를 힘써 행하여 근기가 세 워지면 학문은 지절로 우리 몸 속에 퍼져 들 어온다면 독서에 대해서 별다른 조건을 달 필 요가 없다.35)

일견 보아 글을 읽는 행위와 효(孝)와 제(弟) 는 연결 논리가 분명하게 이해되지 않는 부면이 있다고 할 수 있다. 그러나 동양에서는 전통적으 로 독서 교육에서 독서인의 자세와 기본 마음가 짐을 더욱 중요하게 생각했다. 글 읽는 사람이 기본적으로 갖추어야 할 요소로 효와 제를 주장 한 것은 사물의 본(本)과 말(末) 관계에서 바로 본(本)에 해당한다고 볼 수 있다. 이 점은 독서의 본질과 목적을 언어 사용 기능의 신장이라는 측

33) 丁若鏞, 『與猶堂全書』第一集 第二十一卷

因其廢而善處之 唯讀書一事是已 讀書是人間第一件清 事 不許綺紈子弟知味 又不許章茅村秀才 窥閫奧 必 也以仕宦家子弟 弱歲有聞見 中歲遭罹 如汝輩者 方 可讀書 非謂彼不能讀 徒讀 不名讀耳

34) 丁若鏞, 『與猶堂全書』第一集, 第二十一卷 學問宗旨 本之以孝弟 文之以禮樂 輔之以政刑 翼之以 兵農

35) 丁若鏞, 䑂猶堂全書』第一集第二十一卷

讀書 必須先立根基 根基謂何 非志于學 不能讀書 志 學 必須先立根基 根基謂何 曰惟孝弟是已 先須力行 孝弟 以立根基 則學問自然浹洽 學問兓浹洽 則讀書 不須別講層節耳 
면 보다 거시적 관점에서 나라를 경영하고 백성 을 널리 이롭게 해야 한다고 파악한 정약용의 독 서교육론에 비추어볼 때, 자연스러운 귀결이며 현재 우리의 독서 교육론의 정립에 적지 않은 시 사점을 줄 수 있을 것이다.

\section{III. 조선 후기에 새로운 독서 문화가 제기된 사상사적 배경}

조선 후기에 정약용을 비롯한 일군의 실학자 들에 의해 새로운 독서 문화가 제기된 이유로 다 음 두 가지를 들 수 있다. 곧 조선 중기 이황(李 滉)과 이언적(李彦迪)을 중심으로 한 도학자들에 의해 정점에 이른 성리학이 그 이념적 측면에서 적지 않은 성과를 거두었음에도 불구하고 점점 현실과 유리된 채, 공리공담(空理空談)으로 흐르 는 경향과 과거(科擧) 지향의 정치, 사회 구조가 낳은 편협한 독서 문화에 대한 비판 의식의 고조 가 바로 그것이다.

주지하듯이 우리나라는 중국의 선진문물제도 를 비교적 폭넓게 수용하였다. 도서 또한 예외는 아니어서 조선시대 유생(儒生)들은 중국의 서적, 특히 주자(朱子)로 대표되는 성리학(性理學) 계 통의 도서를 수입하여 이를 널리 읽었다. 다음의 자료들은 주자학을 중심으로 형성된 조선시대 독 서 문화의 단면을 여실히 보여준다.

여러 유생들의 독서는 $r$ 사서(四書)」, 「오 경(五經)」으로 본원을 삼고, 「소학(小學)」, 「 가례(家禮)」로 문호를 삼아야 한다.36)

「사서(四書)」, 「육경(六經)」및 염, 락, 관, 민(주돈이, 정이, 장재, 주희)의 도서는 사람 이 반드시 죽을 때까지 공부하기를 마치 농부 가 오곡을 심듯이 해야 한다.37)

「사서(四書)」와 「오경(五經)」을 순환해서

36) 李滉, 「伊山院規」, 『退溪集』卷四十一 諸生讀書 以四書五經爲本原 小學家禮爲門戶

37）李德惁, 「敎習」, 『靑莊館全書』, 士小節卷三, 「士典」 四書六經及濂洛關閩之書 人須終身藝之 如農夫之藝 五穀也
익숙히 읽어 이해를 그침이 없게 하여 의리가 날로 밝혀지게 하여야 한다. 그리고 송의 선 현들이 지은 책들, 예를 들면 $r$ 근사록(近思 錄)」, 「가례(家禮)」, 「심경(心經)」, 「이정전 서(二程全書)」, r주자대전(朱子大全)」, r어 류(語類)」 및 다른 성리의 학설 등은 틈틈이 정독하여 의리가 항상 내 마음에 젖어들게 하 여 어느 때이고 중단됨이 없어야 한다.38)

이황(李滉), 이덕무(李德惁), 이이(李珥)의 글들 을 통하여 조선시대 유생들의 대체적인 독서 문 화의 경향을 엿볼 수 있다. 선진 유학과 송대 성 리학에 관련된 도서들이 그 중심에 놓여 있다. 특히 송대 주희(朱喜)로 대표되는 성리학 관련 도서는 조선시대 유생과 선비들의 필독서였다. 주자학 일변도의 독서문화의 사상적 의미에 대해 따져보기로 하자.

주자학은 우리나라에서 뿐 아니라 동양의 중 세사회, 특히 한문 문화권에 있어서 하나의 보편 성을 가지다시피 하였다. 말하자면, 주자학은 동 양에 있어서 중세적 세계주의를 이루고 있다. 이 세계주의에 의해서 각 민족의 몰자각한 상태가 지속되었고, 그러한 바탕 위에 우리나라 봉건 교 학의 절대적 권위주의가 구축되었던 것이다.39)

이언적(李彦迪)과 이황 그리고 이이를 정점으 로 학문적 성과에 있어서나 현실적 호용에 있어 서 최고조에 달했던 주자학은 조선 후기로 접어 들면서 그 긍정적, 실질적 역할 면의 하강과 그 부정적 작용면의 상대적인 상승의 추세에 놓이게 되었다. 즉 조선왕조 봉건사회의 해체 과정에 따 른 주자학 자체의 상대적인 비현실성화의 측면과 그것의 운용, 수용에 있어서의 교조적 권위주의 구축이라는 양상을 나타내게 되었다.40) 특히 집

38) 李珥, 「擊蒙要訣」,『栗谷集』卷二十七 五書五經 循環熟讀 理會不已 使義理日明 而宋之先 正所著之書 如近思錄家禮心經二程全書朱子大全語類 及他性理之說 宜閒閒精讀 使義理常常浸灌吾心 無時 間迦

39) 이우성, 「실학연구서설」, 『한국의 역사상』, 창작과 비평사, 1982. p11.

40) 이동환, 「연암의 사상과 소설, 『고전문학을 찾아 서』, 문학과 지성사, 1976. p.210. 
권 세력의 기득권 유지의 방편으로 전락해 버린 주자학은 본래의 기능을 상실하게 되었고, 민중 의 희생을 강요하는 봉건적 예교주의(禮敎主義) 내지 교조적 권위주의의 속성이 더욱 강화되기도 하였다. 이에 따른 결과로 주자학의 윤리 체계 또한 이성우위의 인간관과 상하귀천이라는 등차 적(等差的) 신분 질서를 강조하는 방향으로 변질 되기에 이르렀다. 결국 주자학은 하나의 학설 내 지 사상으로 이해되기보다는 인간의 행동과 사고 를 획일화시키고 사회를 하나의 틀 안에 정체시 켜버리는 부정적 양상으로 변질되었다. 이와 같 이 주자학 계통에 집중된 독서 문화는 그 본래의 학문적 성격과는 상당한 일탈을 보이면서 조선시 대 유생과 학자들의 사고와 행동을 획일적으로 지배하고 현실적인 제반 문제와는 유리된 결과를 놓게 되었다.

정약용은 이와 같은 성리학 일변도의 학문 풍 토의 폐단을 다음과 같이 비판하였다.

성리의 학문은 도를 알고 자기를 알아서 스스로 그 도리를 실천하는 뜻을 힘쓰는 것이 다. ... 지금의 성리의 학문을 하는 사람은 이 (理)니 기(氣)니 성(性)이니 정(情)이니 체 (體)니 용(用)이니 하고, ... 자기에게 들어온 사람은 이를 존대하고 다른 데로 나간 사람은 이를 천대하며, 자기와 학설이 같은 사람은 이를 떠받들고 자기와 학설이 다른 사람은 이 를 공격하면서 자기 스스로 근거한 것은 매우 바르다고 하니 어찌 소활하지 않은가.41)

비록 그들이 외모를 꾸미고 행실을 애쓴 것은 방종하고 간사 음란한 사람보다 나은 점 이 있지만, 빈 속에 고상한 마음으로 거만하 게 제가 옳다고 하니 마침내 손을 이끌어 요, 순, 주공, 공자의 문에 같이 돌아갈 수 없는 것은 지금의 성리의 학문이다.42)

41) 丁若鏞,「五學論」、與猶堂全書』第一集 性 理之學 所以知道認己 其所以踐形之義也...今之爲性 理之學者 曰理曰氣曰性曰情曰體曰用...入者主之 出者 奴之 同者戴之殊者伐之 骵者以爲所據者 極正 峘不 疏哉

42）丁若鏞, 「五學論」, 『與猶堂全書』第一集 第十一卷 雖其修飾邊幅 制行辛苦 有勝乎樂放縱邪淫者 而空腹
성리학에 경도된 당시의 학문 풍토와 학자들 을 위와 같이 비판하면서, 정약용은 "우리나라 사람들은 역사적 사실을 인용한답시고 중국의 일 이나 인용하고 있으니 이건 또 볼품 없는 일이 다. 아무쪼록『삼국사기(三國史記)」, 『고려사(高 麗史)』, 『여지승람(與地勝覽)』, 『징비록(懲毖錄)』, 『연려실기술(練藜室記述)』 및 우리나라의 다른 글 속에서 그 사실을 뽑아내고 그 지방을 고찰하 여 시에 인용한 뒤에 라야 후세에 전할 수 있는 좋은 시가 나올 것이며 세상에 명성을 떨칠 수 있을 것이다." $" 33)$ 라고 말하여, 한국 고전을 중심으 로 한 독서 목록을 제시하는 한편 새로운 독서 문화와 경향을 주장하였다. 또한 “근래 수십 년 이래로 한 가지 괴이한 논의가 있으니 이건 동방 (東方) 문학을 아주 배척하는 일이다. 여러 가지 우리나라의 옛 문헌이나 문집에는 손도 대지 않 으려 하니 이거야말로 병통이 아니고 무엇이나. 사대부 자제들이 우리나라의 옛 일들을 알지 못 하고 선배들이 의론했던 것을 읽지 않는다면 설 사 그 학문이 고금을 ㄲㅞㄸㄸㅀㄱㅗ 있다 해도 저절로 소홀하고 거친 것이 될 뿐이다." $\left.{ }^{\prime 4}\right)$ 말하여 중국 서적 특히 성리학 계통의 글 읽기 풍토를 비판하 는 한편 우리 나라의 일들과 선학들의 의론을 읽 어야 한다는 새로운 독서 문화 패러다임을 거듭 제기하고 강조했다.

조선 후기 실학 시대에 와서 일군의 실학자들 에 의해 새로운 독서 문화가 제기된 또 다른 중 요한 배경 요인으로 과거 급제 지향의 독서 문화 곧 당시까지 양반사대부와 그들의 자제들이 공부 하는 방향이 과거급제를 목표로 한 것이었기 때 문에 현실 사회나 민생의 문제를 해결하는 데 직 접적으로 도움을 줄 수 없는 시. 부 위주의 사장

高心 傲然自是 終不可以携手同歸於堯舜周孔之門者 今之性理之學也

43) 丁若鏞, 「寄淵兒」,『與猶堂全書』第一集

我邦之人 動用中國之事 亦是婳品 須取三國史 高麗史 國朝寶鑑 舆地勝覽 懲毖錄 燃䓠述及他東方文字 採 其事實 考其地方 入於詩用然後 方可以名世而傳後

44) 丁若鏞, 「寄二兒」, 『與猶堂全書』第一集 二十一卷張4 數十年來 怪有一種議論 盛斥東方文學 凡先獻文集 至 不欲寓目 此大病痛 士大夫子弟 不識國朝故事 不見 先輩議論 雖其學 貫穿今古 自是图莽 
지학(詞章之學)으로 흘리 많은 문제점이 노정되 기 시작했다는 점을 들 수 있다.45) 정약용은 "이 세상을 주관하여 천하를 인도하되 창우(倡優), 연 희(演戯)의 기교로써 하는 것은 과거의 학문이다. ...마음을 다스리고 몸을 단속하는 법은 묻는 것 이 아니고, 임금의 잘못을 바로 잡고 백성에게 은택을 베푸는 방법은 생각하는 것이 아니다. ... 경박, 패려한 문사로써 잘한 짓으로 삼고 실상이 없는 말과 거짓말을 말하고 속이는 글과 거짓 글 을 만들어 스스로 그 풍부하고 널리 아는 견문을 자랑하여 하루 동안의 이김을 내기할 뿐이다...한 번 과거의 학문에 빠지게 되면 곧 예악이 자기 이외의 사물이 되고 형정(刑政)이 잡사가 되어, 목민관(牧民官)의 직책을 임명하면 사무에 어두 워서 다만 이속(吏屬)의 지시만 따르게 되며, 조 정에 들어와서 재부(財賦)와 옥송(獄訟)의 관원 이 되면 벼슬자리에 있어 그 직책은 다하지 못하 고 녹(祿)만 타 먹고 있으면서 다만 예전 관례만 묻게 되며, 외직으로 나가서 군사와 국방의 권한 을 맡게 하면 '군대에 관한 일은 배우지 못했다.' 고 하면서 무인을 추천하여 전열에 있게 하니 세 상이 장차 어떻게 되겠는가? ...지금 과거의 학문 도 또한 이미 쇠진해졌다. 세력이 있는 가문과 이름이 있는 문벌의 아들은 이것을 직업으로 삼 기를 즐겨하지 않고, 다만 민간의 추위에 떨고 배고픈 사람들만이 이것을 하게 된다."'46)라고 하 여, 온 세상을 거느리고 온 천하를 몰아서 광대 와 연극 놀음을 하는 것이 과거의 학문이라고 그 폐단을 신랄하게 비판하였다.

과거의 폐단을 인식한 정약용은 유배지에서 두 아들에게 보낸 편지를 통해 "이제 과거에 응

45) 김영, 『조선후기 한문학의 사회적 의미』, 집문당, 1993. 269면

46）丁若鏞, 「五學論」, 『與猶堂全書』第一集第十一卷 主斯世而帥天下 以倡優演戯之技者 科擧之學也...治心 檢身之法 非所聞也 匡君澤民之術 非所意也...澆化悖 戻之辭 以爲能 吐虛吹假 構幺織誕 以自街其贍博之 聞 以賭一日之捷而已 ... 一陷乎科擧之學 則禮樂爲外 物 刑政爲雜事 授之以牧民之職 則夢夢然 唯吏指是 承入而爲財賦獄訟之官 則尸居素食 而唯古例是問 出而操甲兵捍禦之權 則曰 軍旅末之學也 推武人以居 前列 天下將安用矣...今科擧之學 亦已衰矣 巨室名閥 之子 不肯業此 唯田間寒餓者爲之
시할 수 없는 신분이 되었으니 과거 공부로 인해 학문의 영역이 좁아지는 그런 걱정은 안해도 되 겠구나. 내 생각에는 너는 이미 진사쯤은 되었고 과거에 합격할 실력 정도는 족히 된다고 본다. 너도 글을 알기 때문에, 과거 대문에 오는 누를 벗어나는 것과 진사가 되고 급제한 사람이 되는 것 중 어느 편이 나은 일인가는 말하지 않더라도 잘 알 것이다. 네가 진실로 독서할 수 있는 때를 얻게 된것이니, 내가 전에 말한, 'iㅖ족이 되었으 니 더욱 정진해야 한다'라고 한 것이 아니겠느 나"47)라고 말하여, 과거에 응시할 수 없는 좌절 에서 벗어나 오히려 폭넓은 독서 기회를 가지게 된 것이 다행스러운 일이라고 격려하였다. 정약 용은 두 아들에게 “폐족에서 왕왕 기재가 많은데 이것은 다름이 아니라 과거 공부에 얽매이지 않 기 때문이다." ${ }^{48) ㄹ ㅏ ㄱ ㅗ ~ ㄱ ㅓ ㄷ ㅡ ㅂ ~ ㄱ ㅘ ㄱ ㅓ ~ ㄱ ㅗ ㅇ ㅂ ㅜ ㅇ ㅢ ~ i ㅖ ㄷ ㅏ ㄴ ㅇ ㅡ ㄹ ~}$ 강조했고, "일본이라는 나라는 원래 백제에서 책 을 얻어다 보면서 몽매에서 깨게 되었는데 그후 중국의 절강지방과 직접 교역을 트면서 좋은 책 을 모조리 구입하였고, 과거를 보아 관리를 뽑는 그런 못된 짓을 안해서 제대로 학문을 할 수 있 었기 때문에 지금 와서는 그 학문이 우리 나라를 능가하게 되었으니 부끄럽기 짝이 없다"49)라고 말하여 과거의 폐단에서 벗어난 일본의 학문 풍 토와 독서 문화를 추켜세 웠다.

배타적인 성리학과 과거 급제 지향의 학문 풍 토에서 비롯된 편협한 독서 문화를 비판하고 한 국 고전 중심의 새로운 독서 문화를 주장한 정약 용의 담론에서 우리는 고전 독서교육론의 지평을 폭넓게 확보할 수 있을 것이다.

47) 丁若鏞,「寄二兒」, 『與猶堂全書』第一集 第二十一卷 今汝既不能赴科 郎科文已忘憂矣 吾意汝已爲進士矣 已爲及第矣 識字而無科擧之累與爲進士及第者 奚擇 焉 汝眞得讀書時矣 吾所云因其廢而善處之者 非耶

48) 丁若鏞, 「答二兒」, 『與猶堂全書』第一集 第二十一卷 廢族往往多奇才此無他 不爲科擧所累

49) 丁若鏞,「示二兒」, 『與猶堂全書』第一集

大抵 日本本因百濟得見書籍 始甚蒙昧 一自直通江淅 之後 中國佳書無不購去 且無科擧之累 今其文學遠超 吾邦愧甚耳 
교육과정평가연구 제 3 권 제 1 호(2000)

\section{IV . 맺은 말}

이 글은 조선 후기 다산(茶山) 정약용(丁若鏞 : 1762 1836)의 독서교육론의 내용과 성격을 고 찰하여 한국 고전 독서교육론의 이론 정립에 활 용하고자 하였다.

정약용은 독서의 본질 및 대의를 자기 완성이 라는 수기(修己)의 측면에 국한시키지 않고, 나라 를 경영하고 백성에게 혜택을 주는 치인(治人)의 범주까지 그 지평을 확보하였다. 독서의 원리와 방법적 측면에서 정약용은 자기의 의사로 해석하 는 ‘의해'(意解)를 강조하였으며, 독서의 방법 또 한 독서의 본질 및 목적과 관련지어 백성이나 나 라에 도움이 되는 책은 '문단마다 이해하고 구절 마다 탐구'해야 한다는 논의를 전개하였다. 특히 정약용은 글의 독해 과정에서 사물이나 단어의 가장 근원까지 그 의미를 캐고 들어가는 읽기 방 법을 주장하였는데, '격물'(格物)을 독서 방법에 원용한 이론이라고 핱 수 있다. 정약용은 또한 효(孝)와 제(弟)를 독서 군자가 갖추어야 할 근 기(根基)라고 하였다.

조선 후기에 정약용을 비롯한 일군의 실학자 들에 의해 새로운 독서 문화가 태동한 사상사적 배경으로 배타적인 성리학의 폐단과 과거 제도로 인한 편협한 독서 풍토를 제기할 수 있다. 정약 용은 중국 서책 중심의 책 읽기에서 우리 나라 선현들의 책을 중심으로 한 독서 목록을 제시한 한편 우리나라의 일들과 선학들의 의론을 읽어야 한다는 새로운 독서 문화를 주장했다.

정약용의 독서교육론을 분석, 고찰하는 과정에 서 우리는 다음과 같은 과제를 지속적으로 논의 할 필요가 있다. 먼저 독서의 본질 및 목적을 어 떻게 설정할 것 인가하는 문제이다. 다음으로 독 서의 원리 및 방법적 측면에서 '격(格)'의 개념을 독서 방법 및 원리의 측면에서 어떻게 이론화할 수 있을 것인가라는 문제가 새로운 는의거리이 다. 끝으로 각종 고시, 입시 시험 제도와 입신출 세 위주의 책읽기 문화 구조를 혁신시키기 위해 고전 독서교육론에서 우리가 어떤 시사점을 얻을 수 있을 것인가에 대한 진지한 모색이 요청된다. 


\section{참고 문헌}

가. 원전 자료

「論語」

「孟子」

$\ulcorner$ 大學」

$\ulcorner$ 中庸」

「詩經」

「書經」

「易經」

$「$ 春秋」

「禮記」

$「$ 朱子語類」卷 10, 卷 11

「古文眞寶」

$「$ 退溪集」一「言行錄 $1 」 ， 「$ 讀書」

「栗谷全書」一「擊蒙要訣」，「學校模範」

$「$ 靑莊館全書」

「燕嚴集」

$\ulcorner$ 與猶堂全書」

「韓國文集叢刊」, 1 220 冊, 民族文化推進會

徐復觀，「徐復觀先生全集」，臺灣商務印書館

\section{나. 저서 및 논문}

교육부(1997), 「국어과 교육 과정」

김영(1993), 「조선후기 한문학의 사회적 의미」, 집문당.

김왕규(1999), 조선시대 독서법에 관한 소고,

$\ulcorner$ 한자한문교육」 5 , 한자한문교육학회.

김왕규(1992), 율곡 이이의 「학교모범」 연구,

「한문교육연구」 6 , 한국한문교육연구회.

노명완(1986), 새로운 독서 지도, 「어문학보」9, 강원대 사대 국어교육과.

노명완 외(1991), 「국어과교육론」, 갑을출판사.

노명완 외(1995), 「고등학교 독서」, 한샘출판.

노명완(1996), 독서 개념의 현대적 조명, 「독서

연구」 1 , 한국독서학회.

박영목 외(1996), 「국어교육학 원론」, 교학사.

박희병(1997), 「선인들의 공부법」, 창작과 비평사.
박석무(1985), 「유배지에서 보낸 편지」, 시인사. 신헌재 외(1993), 「독서교육의 이론과 방법」, 박이정.

신헌재 외(1997), 「학습자중심의 국어교육- 그 원리와 방법」, 박이정.

이재승(1998), 「국어교육의 원리와 방법」, 박이정

이재승(2000), 정보화 사회와 독서 교육, 「독서 교육연구 5 , 한국독서학회.

이우성(1982), 실학연구서설, 「한국의 역사상』, 창작과 비평사.

이동환(1976), 연암의 사상과 소설, 「고전문학을 찾아서 $\lrcorner$.

천경록 외(1997), 「읽기 교육의 이해」, 우리교육.

초등국어교육학회, 「읽기 수업 방법」, 박이정. 


\title{
AB ST RACT
}

\section{Exploring A Theoretical ground about Yakyong Chung's Reading Comprehension}

\author{
Wangkyu Kim \\ (KICE)
} This study aims to explore a theoretical
ground about Yakyong Chung $(1762 \sim 1836)$ 's
Reading Comprehension and compare the
characteristics of Reading Comprehension in
Chosun Dynasty with modern society.
The results can be summarized as follows;

This study indicates that it is important to discuss the essential qualties of Reading Comprehension and how to apply the concept of '格' to Reading comprehension in terms of methods and principles.

Key words : the characteristics of Reading Comprehension , 格 